\title{
Are clearcuts appropriate for the mixed forest of Québec?
}

\author{
by Rémi Hébert ${ }^{1}$
}

Sustainable forest management involves, among other things, maintaining diversity of ecosystems and preserving their natural processes. The main objective of this paper is to consider the validity of current harvesting techniques applied to the mixed forest of Québec. The old-growth mixed forest naturally regenerates by gap dynamics. However, the harvesting technique most commonly used in the mixed forest is clearcutting, with the result that succession must start over from the beginning. A general forest succession model applicable after such large disturbances is proposed. The most positive estimate indicates that the mixed forest will not be re-established earlier than 250 years after clearcutting. To ensure sustainable development in the mixed forest, harvesting techniques should imitate natural regeneration processes.

Key words: balsam fir-yellow birch stands, CPRS, gap dynamics, succession model, sustainability, sustainable development

Le développement durable des forêts implique, entre autres, le maintien de la diversité des écosystèmes et la conservation de leurs processus naturels. L'objectif principal de cette étude était donc de discuter des techniques de récolte actuelles: sont-elles adaptées pour la forêt mixte au Québec? La forêt mature mixte se régénère naturellement par des petites ouvertures. Cependant, la technique de récolte qui est la plus communément utilisée en forêt mixte est la coupe à blanc. Le principal résultat est que la succession repart du début. Nous proposons donc un modèle général de succession forestière après d'aussi grandes perturbations. Notre estimation la plus positive indique que la forêt mixte ne sera pas de retour avant au moins 250 ans après la coupe à blanc. Afin d'assurer le développement durable dans la forêt mixte, les techniques de récolte devraient imiter son processus naturel de régénération.

Mots clés: CPRS, développement durable, durabilité, dynamique par trouée, modèle de succession, sapinière à bouleau jaune

\section{Introduction}

Sound forest management must protect, maintain and preserve the vitality of forest ecosystems for the benefit of all living species (Ministère des Ressources naturelles du Québec 2000a). Forest exploitation must then be closely tied with sustainable development in order to maintain forests and wildlife. Sustainable forest management involves, among other things, maintaining the diversity of ecosystems and preserving their natural processes (Ministère des Ressources naturelles du Québec 2000a). Knowledge of these ecosystems is essential for understanding the impacts of certain harvesting techniques on regeneration. In fact, their natural processes should be respected if we want the same kind of forest to grow back. It is also important to maintain old-growth forests or some of their characteristics on a permanent basis, since they provide shelter for particular animal and plant species (Ministère des Ressources naturelles du Québec 2000a).

The notion of sustainable development was originally linked to the notion of intergenerational equity - the moral obligation to bequeath to following generations a healthy environment with natural resources as abundant as they were at the time that we received them from our elders (Di Castri 1995). The expression "sustainable development" thus inevitably has an ecological connotation. However, Di Castri (1995) included four components for sustainable development: economic, environmental, social and cultural. Di Castri (1995) even represented sustainable development as a chair, with four legs of equal length and solidity, each of them (alone and in interaction with the others) corresponding to one of its main components. If one leg is shorter or not as solid as the others, the

${ }^{1}$ Département de biologie, Pavillon Alexandre-Vachon, Université Laval, Québec (Québec) G1K 7P4. E-mail address: remi_hebert@hotmail.com chair will neither be stable nor comfortable and there will be no durability (Di Castri 1995).

One prerequisite for sustainable development is the sustainable use of the available stock of natural resources (Cairns and Meganck 1994). The concept of sustainable development has its greatest application in biological systems, particularly forestry (Hall 2001). In order to report on progress toward achieving sus-

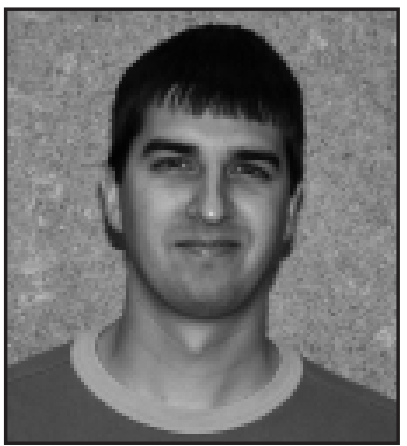

Rémi Hébert tainable forest management, one must understand the changing nature of forests so as to identify when change is induced by human intervention, and how this change affects sustainability (Hall 2001). In fact, when disturbances and stress remain at levels within the range of natural variation and the biological components and processes of the forest are maintained, the health of the forest will also be maintained since forest ecosystems are inherently dynamic and adapted to change and stress (Hall 2001). Stresses beyond the limits of tolerance can thus be expected to adversely affect sustainability (Hall 2001). It is difficult to define all the interrelationships and needs of species or processes within an ecosystem, but recognition of historic disturbance regimes and habitat conditions is helpful for providing a framework for the interpretation of current data and information (Hall 2001).

At all times, nature should be the main guide for work done in the forests (Ministère des Ressources naturelles du Québec 2000a). The main objective of this paper is to consider the validity of current harvesting techniques applied to the mixed forest. To this end, a comparison will be made with its natural regeneration process. 


\section{Discussion}

The mixed forest vegetation zone mainly contains stands of balsam fir (Abies balsamea (L.) Mill.) and yellow birch (Betula alleghaniensis Britt.) together (Ministère des Ressources naturelles du Québec 2000b). The mixed forest corresponds to the bioclimatic domain of the balsam fir-yellow birch forest, which covers $6 \%$ of Québec's territory_about $95000 \mathrm{~km}^{2}$ (Ministère des Ressources naturelles du Québec 2000b). The mixed forest marks the transition between the hardwood forest, dominated by sugar maple (Acer saccharum Marsh.), and the boreal forest, dominated by balsam fir and black spruce (Picea mariana (Mill.) BSP.) (Ministère des Ressources naturelles du Québec 2000b). The mixed forest forms a unique, stable in time, forest entity (Lalumière and Thibault 1988, Ministère des Ressources naturelles du Québec 2000b).

The mixed forest is of great importance in Québec. It contains high quality wood and has a great wildlife potential. In a study of its natural regeneration process, Hébert (2000) found that the old-growth mixed forest of La Mauricie National Park regenerates by gap dynamics. This process operates on a very small spatial scale, often on a scale of only one tree. When one tree of the canopy falls, it creates a gap. A greater proportion of light then reaches the soil surface. The new incoming light stimulates regeneration. Finally, from the regeneration in the gap, only one or two trees will be able to reach the canopy to eventually replace the one that created the gap and generate growth.

Mountain maple (Acer spicatum Lam.) was the most abundant species in gaps of the old-growth mixed forest (Hébert 2000). However, all main canopy species were present at the regeneration level. Balsam fir was as abundant in gaps as under the forest cover (Hébert 2000). It is a relatively shade-tolerant species as its seeds can germinate under the forest cover and young stems can survive. Balsam fir then needs gaps only to reach the canopy, not to reproduce. Yellow birch was more abundant in gaps than under the forest cover (Hébert 2000). It is usually classified as an intermediate in shade tolerance. However, it needs strong light to enable seed germination and the survival of young stems. Gaps are thus beneficial to yellow birch by enabling new stems to become established.

The harvesting technique that is currently more commonly used in the mixed forest is clearcutting. Clearcuts are generally large areas where the majority of mature trees have been removed. Before the 1990s, total cuts were used. However, over the past few years, ensuring regeneration of cutblocks has become mandatory (Gouvernement du Québec 1996). Clearcuts are now known as "cuts with protection of the regeneration and soils" (CPRS). The objective of CPRS is to protect advance regeneration from damage during harvesting so that it will ensure regeneration of the forest after mature trees are removed. However, CPRS does not seem to be effective in the mixed forest, especially since yellow birch has less regeneration under forest cover. Advance regeneration tends to be overwhelmed by species that compete strongly in full light. The main result is that succession must start over from the beginning.

After a clearcut in the mixed forest, early colonizing species are the first to become established. Early colonizing species include raspberry (Rubus idaeus L.), which is a specialist of open or disturbed areas. As noted by Whitney (1986), it is often a dominant element of the shrub layer of windthrows, burned areas or clearcuts. In fact, following large-scale disturbances, it often forms a mono-specific shrub layer that competes with tree seedlings for light, soil moisture and nutrients (Whitney 1982, Harvey et al. 1995, Ricard and Messier 1996, Lautenschlager 1999). Raspberry is a relatively shade-intolerant species (Whitney 1982). Whitney (1986) recognizes two phases in the history of a raspberry stand. The first phase is the "building phase," in which relatively open site conditions ensure that most root suckers produced at this time will develop into independently functioning stools. The initial success of raspberry can be attributed to a high investment in vegetative propagation, favouring the pre-emption of the site's resources while conditions are still favourable for its growth (Whitney 1982). Full occupancy of the site normally occurs at the end of the second or third year and indicates a shift to the "self-thinning phase" of the stand developmental history. Intense intraspecific competition during the self-thinning phase eliminates many of the smaller individuals in the growth hierarchy and most newly formed suckers. As conditions for vegetative propagation deteriorate, raspberry shifts to the production of large numbers of seeds and a large seed bank is established to reinitiate the cycle. As Whitney (1986) concluded, from a temporal standpoint, the most dynamic history of the stand, above ground, is only a brief interlude in the longer, slower moving history of the seed bank below ground.

Cover development of the early colonizing species, such as raspberry, tends to be more rapid than the woody species (Bell et al. 2000). It often offers substantial competition against woody species. Many authors reported that raspberry competition hinders the growth of woody species (Ruel 1992, Bell et al. 2000, Jobidon 2000). For instance, Whitney (1986) reported that the mean density of raspberry was 61 plants $/ \mathrm{m}^{2}$ in a harvested site. More specifically in the balsam fir-yellow birch bioclimatic domain, Jobidon and Charette (1997) reported that mean density of raspberry in clearcuts was 18.6 plants $/ \mathrm{m}^{2}$. In another study, Jobidon (2000) reported that two years after harvesting, raspberry density was 9.72 plants $/ \mathrm{m}^{2}$ whereas seven years after harvesting, it increased to 16.80 plants $/ \mathrm{m}^{2}$. In contrast, in natural gaps of the old growth mixed forest, Hébert (2000) found that raspberry density was 0.25 plants $/ \mathrm{m}^{2}$. It appears that competition is much less in small gaps than in clearcuts. This may be an indication as to why yellow birch establishes itself in natural gaps, whereas succession starts over from the beginning in clearcuts.

The occurrence of early colonizing species is transitory. According to Whitney (1986), raspberry rarely persists in any appreciable numbers beyond the tenth year after harvesting. In the mixed forest, De Grandpré et al. (2000) reported that the coverage of raspberry, five years after harvesting, was $63 \%$ and decreased to $53 \%$ the tenth year after harvesting. Raspberry cover decreased to $2 \%$ by 20 years after harvesting (De Grandpré et al. 2000). Early colonizing species gradually give way to other larger colonizing species. Fig. 1 and Fig. 2 illustrate this situation. Larger colonizing species are represented here by mountain maple and paper birch (Betula papyrifera Marsh.) as examples.

Mountain maple is a shrub species reaching only 5-6 m at maturity (Lei and Lechowicz 1990, Marie-Victorin 1995). Mountain maple can also become well established following harvesting and can form a very dense canopy (Post 1970, Archambault et al. 1998). For example, in northwestern New Brunswick, Post (1970) reported that eight years after clearcut- 


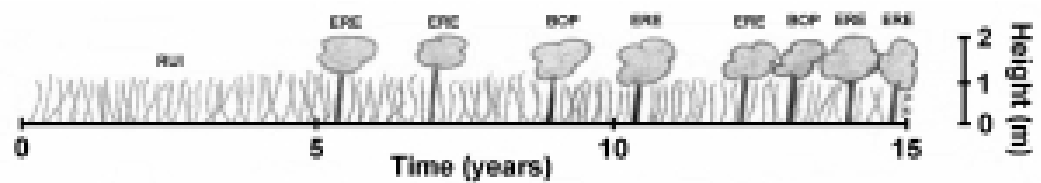

Fig. 1. Between 0 and 5 years after a clearcut in the mixed forest, early colonizing species that are specialists of disturbed areas, represented here by Rubus idaeus (RUI), are established at very high densities. Gradually, from 5 to 15 years after harvest, larger colonizing species become dominant, like Acer spicatum (ERE) and Betula papyrifera (BOP). Illustrated species serve only as examples.

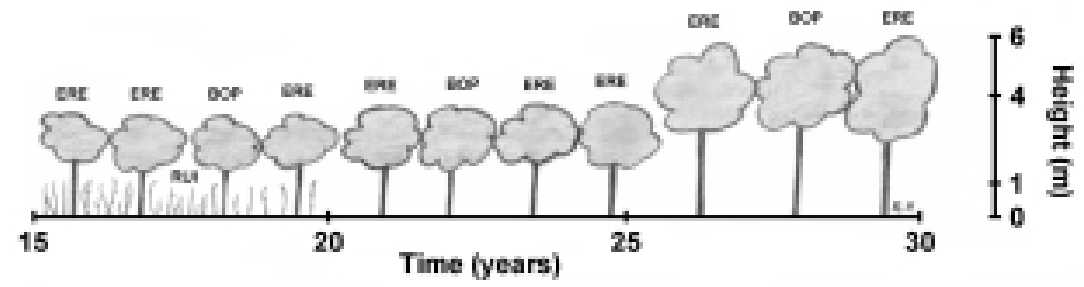

Fig. 2. From 15 to 20 years after a clearcut in the mixed forest, a new canopy of woody species of approximately $4 \mathrm{~m}$ height is formed over the early colonizing species, represented here by Rubus idaeus (RUI). From 20 to 30 years after harvest, Rubus idaeus has completely disappeared and larger colonizing species, like Acer spicatum (ERE) and Betula papyrifera (BOP) continue their growth. Illustrated species serve only as examples.

ting, mountain maple density was 33300 stems/ha. At 11 years after harvesting, its density was 22800 stems/ha. It then decreased to about 18400 stems/ha 13 and 16 years after harvesting. After 18 years, its density was 8500 stems/ha. Finally, from 21 to 26 years after clearcutting, it stayed stable at about $6700 \mathrm{stems} / \mathrm{ha}$. In the mixed forest, Vallée et al. (1976) found that five years after a clearcut in a balsam fir-yellow birch stand, mountain maple density was of 8870 stems/ha. Also five years after harvesting, Laflèche et al. (2000) found that mountain maple density was of 29730 stems/ha. In another study, Bédard et al. (1978) found that eight years after clearcutting, mean density of mountain maple was 10600 stems/ha. They also found that it was of 23500 stems/ha 10 years after harvesting and that it was of 18550 stems/ha 12 years after harvesting. Archambault et al. (1998) found that density was approximately 33000 stems/ha five years after harvesting, whereas it was between 21000 and 23000 stems/ha 10 and 20 years after harvesting. By looking at the mean percent cover, De Grandpré et al. (2000) found that mountain maple covered $63.3 \%, 75.1 \%$ and $99.7 \%$ respectively 5,10 and 20 years after clearcutting. Density values vary among studies. It is possible that browsing intensity by herbivores and threshold stem height may have influenced the densities.

Post (1970) reported that the height of the mountain maple stand at $8,11,13,16,18,21,23$ and 26 years after harvesting was $1.9,2.7,3.2,3.4,4.7,5.5,5.3$ and $5.4 \mathrm{~m}$, respectively. In the mixed forest, Laflèche et al. (2000) reported that mean height of mountain maple was $1.7 \mathrm{~m}$ five years after harvesting. Bédard et al. (1978) reported that it varied between 1.3 and $2.2 \mathrm{~m}$ from eight to 12 years after harvesting. Finally, Archambault et al. (1998) reported that mean height was about $1.3 \mathrm{~m}$ five years after harvesting, whereas it was near $2.0 \mathrm{~m} 10$ and 20 years after harvesting.

Mountain maple is also very common in gaps of the old-growth mixed forest. Hébert (2000) found that its density was 16765 stems/ha, which is comparable to densities found in clearcuts. Based on the low rates of regeneration by seed, together with its habit of producing basal sprouts and spreading later- ally through stem layering, Lei and Lechowicz (1990) suggest that mountain maple relies heavily on vegetative means to more effectively discover and exploit light gaps. Jobidon (1997) and Vincent (1965) also discuss its vegetative reproduction. In fact, rapid height growth of layered shoot sprouts fed by the parental stem enables a quick response to the presence of even very small gaps (Lei and Lechowicz 1990). This may explain its relatively high density in natural gaps as an alternate mode of adaptation to the understory environment (Lei and Lechowicz 1990). Since light intensity is less in natural gaps than in clearcuts, mountain maple might not be as vigorous in the gaps as in clearcuts.

Ultimate conditions in clearcuts and gaps are likely to be different. In gaps, only one stem has to reach the canopy in order to re-close the forest cover. In clearcuts, the whole canopy must be re-established. At this stage, distinction between arborescent and shrub species can be made among the larger colonizing species (Fig. 3). According to Vallée et al. (1976), mountain maple, beaked hazelnut (Corylus cornuta Marsh.) and Appalachian tea (Viburnum cassinoides L.) were the most abundant larger colonizing species, all being shrub species. As for tree species, balsam fir, aspen (Populus tremuloides Michx.) and paper birch were also present, but with lower densities (Vallée et al. 1976). Yellow birch density was only 110 stems/ha (Vallée et al. 1976). In another study, again after harvesting in the mixed forest, Bédard et al. (1978) reported that mountain maple, beaked hazelnut and balsam fir now dominated the site they studied. Jobidon and Charette (1997) reported that deciduous colonizing species were represented, in decreasing order, by pin cherry (Prunus pensylvanica L.f.), mountain maple, paper birch and aspen. When considering only stems with a diameter at breast height $(\mathrm{dbh})$ between 1 and $9 \mathrm{~cm}$, Archambault et al. (1998) found that paper birch was the most abundant overstory species 20 years after harvesting ( 875 stems/ha), followed by sugar maple (475 stems/ha). Yellow birch density was only 75 stems/ha (total density $<500$ stems/ha). However, when looking at the mean height of the stems 20 years after harvesting, the two tallest species were paper birch and yellow birch, 


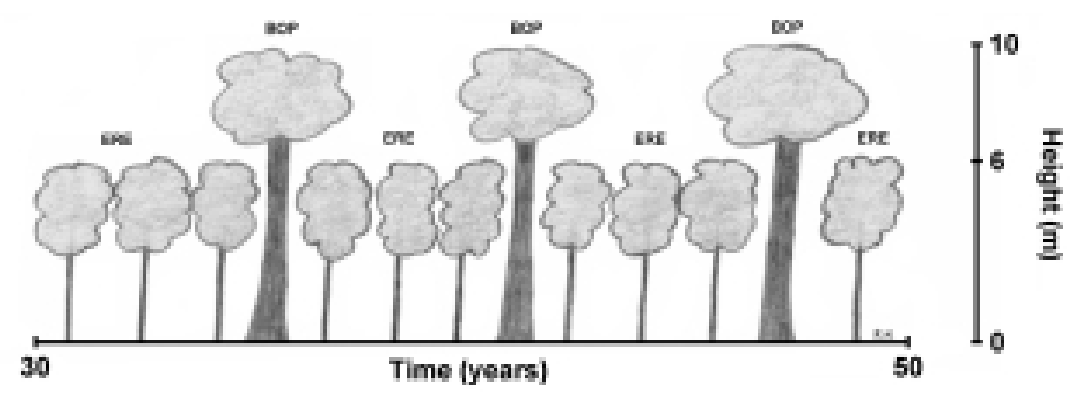

Fig. 3. From 30 to 50 years after a clearcut in the mixed forest, distinction can be made between shrub colonizing species, represented here by Acer spicatum (ERE), and arborescent colonizing species, represented here by Betula papyrifera (BOP). The shrub species reach their maximum height of approximately $6 \mathrm{~m}$ whereas arborescent species continue their growth. Illustrated species serve only as examples.

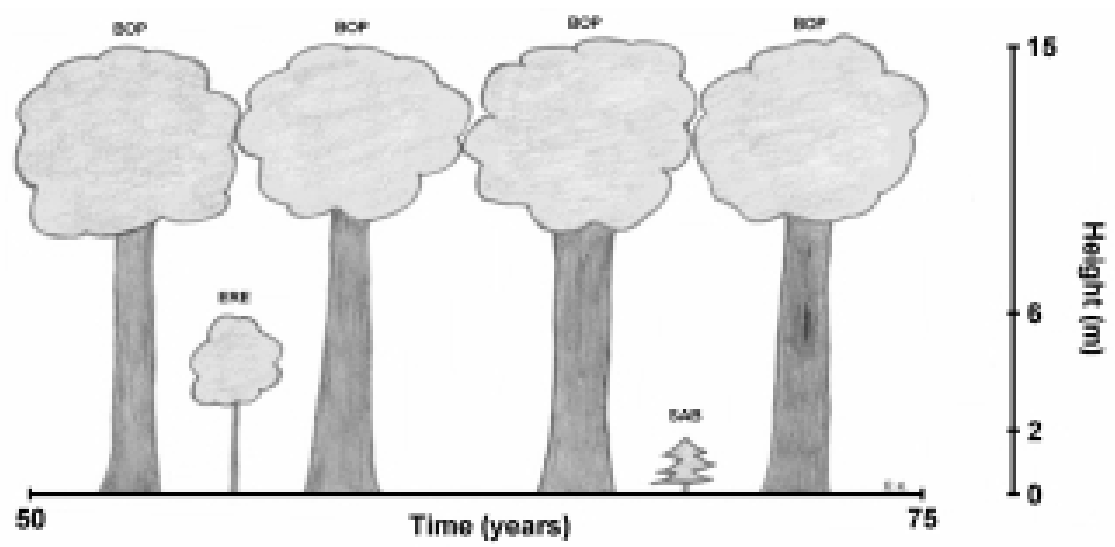

Fig. 4. From 50 to 75 years after a clearcut in the mixed forest, a new canopy of approximately $15 \mathrm{~m}$ height is formed. It is composed of arborescent colonizing species, represented here by Betula papyrifera (BOP). Since available light is reduced at the shrub layer, colonizing shrub species, represented here by Acer spicatum (ERE), gradually disappear. Relatively shade-tolerant climax species, such as Abies balsamea (SAB), then begin to become established. Illustrated species serve only as examples.

at approximately $4.5 \mathrm{~m}$ in height. Sugar maple was clearly not a part of the current canopy, with a mean height of about $0.5 \mathrm{~m}$. De Grandpré et al. (2000) also confirmed that sugar maple was not likely to form the next forest. Finally, Laflèche et al. (2000) reported that in most cases, yellow birch had regenerated poorly five years after harvesting and had a mean density less than 1500 stems/ha. In comparison, paper birch was relatively abundant with a mean density of more than 4700 stems/ha. Paper birch was taller five years after harvesting, since almost $50 \%$ of its stems attained a mean height between 1 and $3 \mathrm{~m}$. Paper birch also grew more quickly than yellow birch (Laflèche et al. 2000). In clearcuts, arborescent colonizing species are more likely to form the next canopy than climax species (Fig. 4).

Balsam fir does not perform well in clearcuts. According to Archambault et al. (1998), deciduous colonizing species had completely over-topped the coniferous species present. In fact, 20 years after harvesting, balsam fir mean height was approximately $1 \mathrm{~m}$ (Archambault et al. 1998). Laflèche et al. (2000) reported that balsam fir was under the cover of all other species five years after harvesting, even if it had regenerated very well. Mountain maple frequently forms pure, dense stands that hinder the establishment of balsam fir and spruce regeneration (Post 1970). Young conifers associated with species like mountain maple are unable to compete successfully for light, water and nutrients, leading to failure of coniferous regeneration (Ruel 1992, Jobidon 1997). Batzer and Popp (1985) also reported that balsam fir regeneration was more abun- dant when shrub density was low. After having manually and chemically released balsam fir seedlings from shrub competition (mountain maple) in northwestern New Brunswick by clearing a 1-m radius circle around each seedling, MacLean and Morgan (1983) reported an increase of $64 \%$ for total fir volume, $36 \%$ for mean dbh, and $22 \%$ for mean height, in comparison with a control plot, 32 years later. Finally, Carleton and MacLellan (1994) reported that a higher proportion of plantations fails due to competitive suppression by, and superior growth of, broad-leaved deciduous shrubs and trees invading the site. This situation may last for a long period of time. Archambault et al. (1998) reported that the oldest mountain maple stem was 53 years old, measured $5.6 \mathrm{~m}$ and had a diameter at stump height of $5 \mathrm{~cm}$. Balsam fir exhibits characteristics of a climax species.

Paper birch is used here as an example and will certainly not form a pure stand everywhere. Any of the other arborescent colonizing species previously cited could be present. However, when the new stand approaches maturity, shrub colonizing species, such as mountain maple, lose influence and shade-tolerant climax species, such as balsam fir (Ruel 1992), may become reestablished under the forest cover (Fig. 5). Later, when the first paper birch trees deteriorate and form gaps in the canopy, preestablished shrubs will be able to reach the canopy. Other lightdemanding climax species, such as yellow birch, will become established (Fig. 6). Hébert (2000) found that in gaps of the oldgrowth mixed forest, yellow birch mean density was 3078 stems/ha 


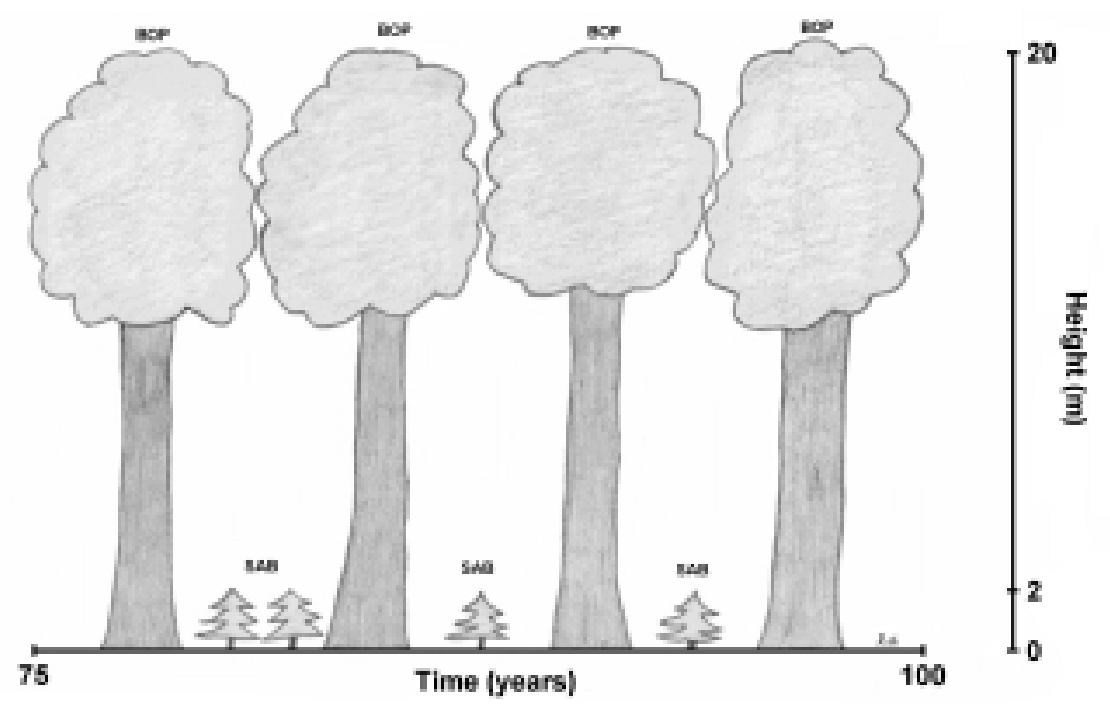

Fig. 5. From 75 to 100 years after a clearcut in the mixed forest, arborescent colonizing species, represented here by Betula papyrifera (BOP), reach their maximum height of approximately $20 \mathrm{~m}$. However, since Abies balsamea (SAB) is still in a low-light environment, it cannot reach the canopy. Illustrated species serve only as examples.

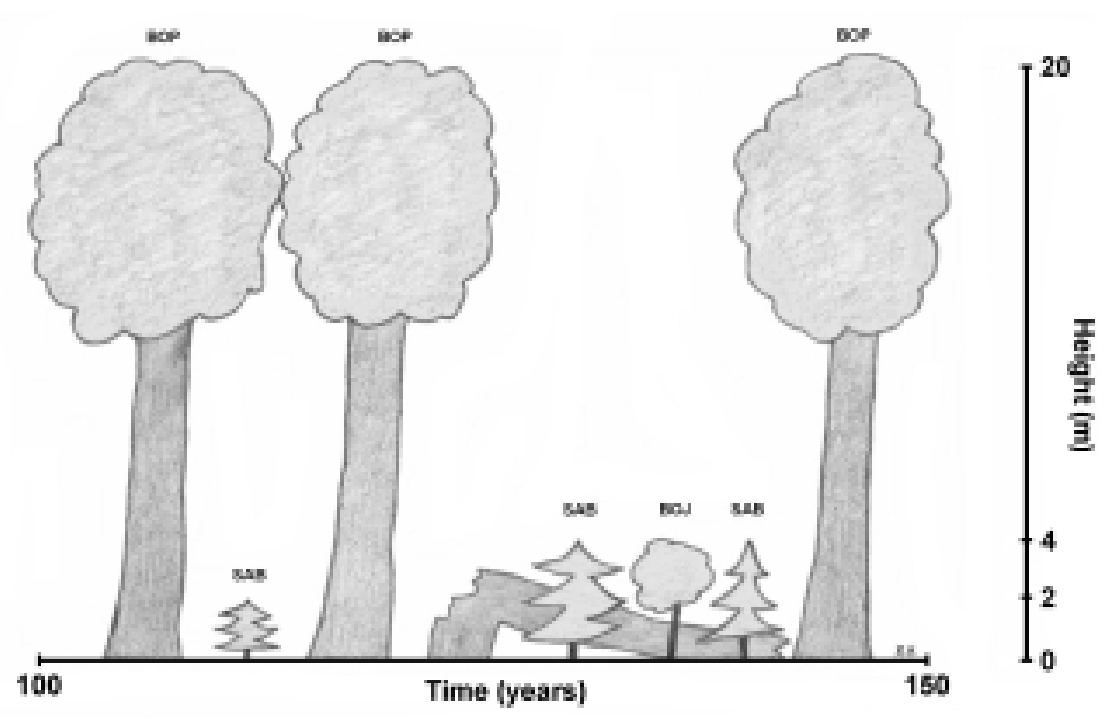

Fig. 6. From 100 to 150 years after a clearcut in the mixed forest, the first gaps are created by the death of the first mature trees of the arborescent colonizing species, represented here by Betula papyrifera (BOP). In gaps, climax species such as Betula alleghaniensis (BOJ) become established while Abies balsamea (SAB) begins its growth towards the canopy. Illustrated species serve only as examples.

compared to 620 stems/ha under the forest cover. In contrast, paper birch does not appear able to establish itself in gaps. Mean density in gaps was 74 stems/ha and 53 stems/ha under the forest cover. Nevertheless, paper birch was present in the canopy (Hébert 2000). As one possible explanation, Lalumière and Thibault (1988) reported that this transition species is directly linked to old forest cuts, and should then continue to regress, giving way to climax species. Since Hébert (2000) found that paper birch regeneration was almost absent in the old-growth mixed forest, this tends to confirm the hypothesis that its presence is mainly due to past forest harvesting.

Although paper birch reaches maturity at about 70 or 80 years, maximum longevity is between 150 and 200 years (Marie-Victorin 1995). However, in the southern part of the Canadian bore- al forest, Bergeron and Dubuc (1989) found many paper birch trees over 200 years old. It is, thus, possible that the majority of gaps will form between 150 and 200 years after the standreplacing disturbance. During that time, regeneration of the climax species in the first gaps will continue their growth (Fig. 7). Finally, at about 250 years, the original stand composition should be observable (Fig. 8).

In the proposed general forest succession model, it is assumed that the mixed forest will eventually be re-established. It is also assumed that this will take place without further human interventions. In fact, in Québec, large forest areas of the balsam fir-yellow birch domain are currently planted with black spruce (Jobidon and Charette 1997), in which case the mixed forest is gone forever. 


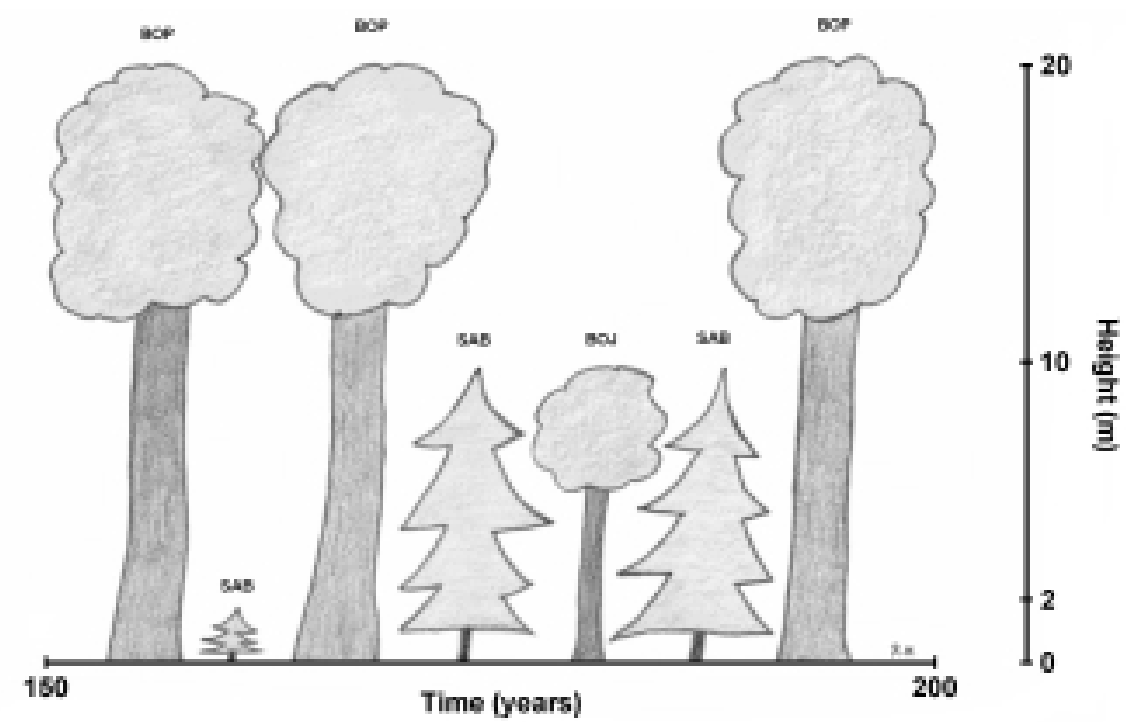

Fig. 7. From 150 to 200 years after a clearcut in the mixed forest, climax species, such as Betula alleghaniensis (BOJ) and Abies balsamea (SAB), continue their growth in the first gaps. Since the maximum longevity of Betula papyrifera (BOP) is between 150 and 200 years, the majority of gaps are most likely to be created during this period. Illustrated species serve only as examples.

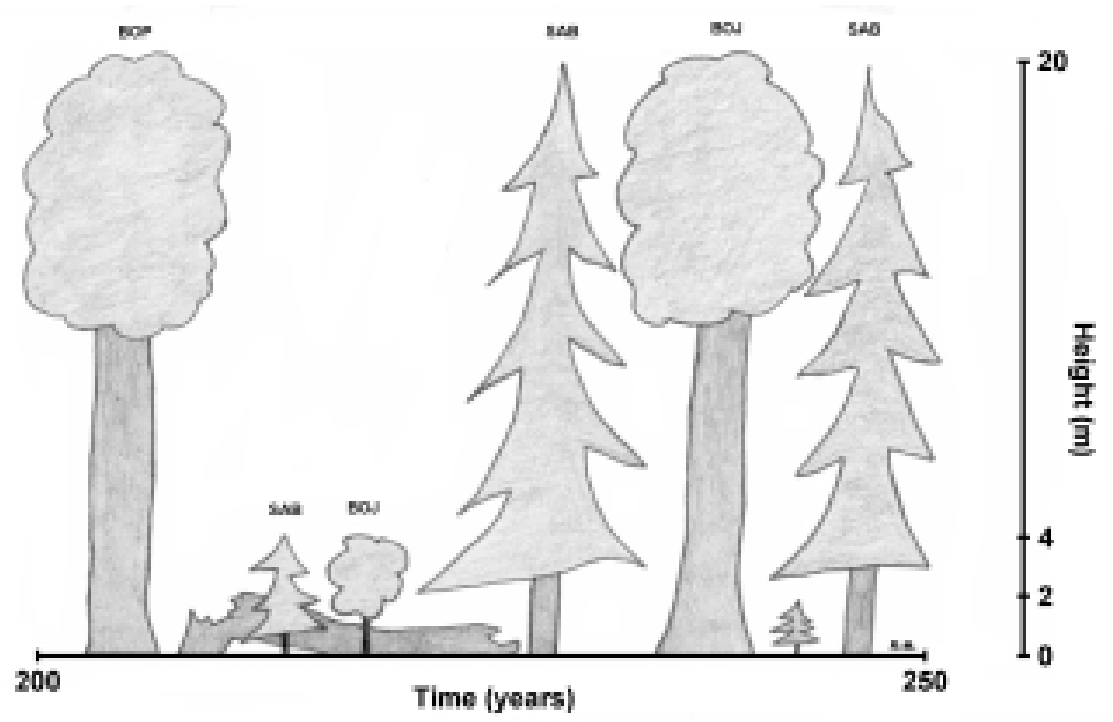

Fig. 8. From 200 to 250 years after a clearcut in the mixed forest, the last mature trees of Betula papyrifera (BOP) create their last gaps. In the gaps, climax species such as Betula alleghaniensis (BOJ) become established and Abies balsamea (SAB) begins its growth towards the canopy. Mature trees of climax species such as Betula alleghaniensis and Abies balsamea, originating from the first gaps, now form the new mixed forest 250 years after harvesting. Illustrated species serve only as examples.

Oliver (1981) described a general pattern of forest development following major disturbances, and discussed a mechanism by which the same area could be dominated potentially for extended periods by entirely different forest communities. He divided forest development into four broad stages: stand initiation, stem exclusion, understory re-initiation, and old growth. The period during which new seedlings actively invade or begin growth following a disturbance is referred to as the "stand initiation stage." The developing individuals enlarge and utilize available growing space until one or more environmental factors become limiting. Species gaining competitive advantages are those that grow quickly following the preceding disturbance. A stand development stage then occurs during which new stems cannot become established. This is the "stem exclusion stage." In addition to the exclusion of new stems, there is also intense competition among existing stems. After a period of intense competition, vertical stratification of trees occurs, whereby one or several species become dominant and suppress other species' growth. The eventual dominant species is not necessarily the species that was largest or most numerous in the beginning. The "understory re-initiation stage" then follows. The overstory forest eventually appears to lose its exclusivity on the site. Understory herbaceous and woody plants, including tree species that can exist as advance regeneration, begin to grow in the favourable parts of the understory. The length of time before this understory re-initiation begins 
seems to depend on the tolerance of the overstory as well as on the frequency of minor perturbations. Finally, at the "oldgrowth stage," Oliver (1981) reported that eventual fates of the understory and overstory in the absence of a major disturbance are unclear. In the case of the mixed forest, we know that oldgrowth forest is driven by gap dynamics. The mixed forest can regenerate itself continuously, without starting over from the very beginning of the vegetal succession. Apart from details in the last stage, our approach is comparable with the general pattern of forest development after major disturbances suggested by Oliver (1981).

Clearcuts in the mixed forest exceed normal ecosystem stress thresholds. Many natural impacts do not affect sustainability if not impacting forests beyond the natural limits of variability, because forests have reached some level of adaptation to these stresses. In fact, in a mature hardwood forest in the northeastern United States, natural canopy openings such as those formed by stem-snapping, uprooting of trees and pathogen irruption are less disruptive to the understory, leaving undisturbed forest floor that ranges from 64 to $100 \%$ in area (Hughes and Fahey 1991). This suggest that an important distinction exists between disturbances that result in undisturbed forest floor (where long-term spatial patterns are preserved but disguised by short-term changes in species importance) and truly disruptive disturbances (which destroy pre-existing spatial patterns and initiate successions that are not spatially predictable) (Hughes and Fahey 1991).

Kessell (1981) noted that it is difficult to predict forest succession after a large spatial scale disturbance. However, he argued that managers should adapt, refine and apply existing tools to their own areas and decisions. By setting forth our general succession model, our goal is to apply these suggestions to the mixed forest. Also, current forest harvest plans assume a clearcut rotation every 90 to 120 years. To maintain sustainable development and protect biodiversity, this is not realistic.

On a worldwide scale, integrated forest management focuses on reducing deforestation since conversion, destruction, and simplification of natural forests (e.g., clearcutting and replacement with monoculture plantations) are the primary causes of large biodiversity losses (Cairns and Meganck 1994). In virtually all cases, forest ecosystems have been significantly modified by human activities over the past centuries and millennia (Chapin et al. 1996, Norton 1996). Biodiversity has been impacted at the ecosystem, species, population and genetic levels (Norton 1996). The geographic range of many species has been reduced, and, in a number of cases, species have become extinct (Norton 1996). The conservation of biodiversity requires that all living species should be systematically inventoried, broadly appreciated, and utilized in ways that are equitable and sustainable (Miller 1994, Prance 1995). All sectors of the economy (agriculture, forestry, industry, tourism, etc.) should work closer together to enable a rational territory management at the regional, national and worldwide scales (Upreti 1994, Di Castri 1995, Lemons 1995, Hall 2001).

Sustainable management of forest ecosystems and conservation of biological diversity are now promoted as goals by most nations (Norton 1996). However, Boer (2000) affirmed that without a holistic and integrated approach, the continuation of business as usual can be expected for the most part, with national governments often going in different directions from each other, and the private sector going about its usual business. Hence, some authors think that sustainable development should be legislated (Lemons 1995, Boer 2000). Nevertheless, a statement of Forest Principles was ratified by governments and released at the Earth Summit. This is a non-legally binding document outlining the principles for a global consensus on the management, conservation and sustainable development of all types of forests (Norton 1996).

\section{Conclusion}

Forests are a priceless collective inheritance (Ministère des Ressources naturelles du Québec 2000a). Integrated forest management must be established as the standard approach; the size of protected areas must be increased; and forest biodiversity must be maintained at all costs (Ministère des Ressources naturelles du Québec 2000a). In all cases, biodiversity has become a central objective. This objective can be met by ensuring that forests are managed in a way that allows the natural diversity of their ecosystems to be maintained or restored. Indeed, sustainable use involves keeping a large number of biological interactions intact (Prance 1995). In general, most temperate and boreal forest ecosystems are poorly protected (Norton 1996). Yet protected areas play an important role in maintaining and understanding biodiversity (Miller 1994). Stated simply, biodiversity must be saved, studied and used wisely (Miller 1994).

The mixed forest is of great importance in Québec. Yellow birch is even the arboreal emblem of Québec. However, current harvesting techniques are not appropriate. Several studies are under way to propose new approaches. They merit close attention to ensure the presence of the mixed forest in our future. Management of the mixed forest is a great challenge. How do we manage a forest that continuously regenerates without catastrophic disturbances? When can harvesting begin? How should harvesting be done? In response to those questions, we think that nature should serve as guide. Selective cuts, or gap-like cuts, should be implemented in the mixed forest instead of large clearcuts.

Much has been said about the difficult, if not impossible, conceptual nature of sustainable development (Jickling 2000). For many, a more viable option has been to shift focus to "sustainability." However, now is the time to look closer at the problems associated with emphasizing sustainability as an organizing concept. Jickling (2000) argues that as important as it is, this term is not sufficient to explain or direct our imperatives; it may even mask important distinctions. At present, promoters of ecology and industry can, with public approval, both use the term "sustainability" to support radically different values. The term "sustainability" tends to disguise contradictions. In this sense, "sustainability" tends to blur the very distinctions required to thoughtfully evaluate an issue (Jickling 2000).

In the new Québec Forest Act, there has been a shift towards "increased yield," which is an increase in the allowable annual cut obtained by intensifying forest management. In fact, the available wood supply from public forests in Québec has almost all been allocated. An increased yield policy only aims at sustainability, not at sustainable development. As for the mixed forest, instead of further intensifying its management, we should more closely imitate its natural regeneration process.

\section{Acknowledgements}

Thanks go to Louis Archambault for reviewing the manuscript. I would also like to thank Mireille Marcotte and Jean Huot for their support. 


\section{References}

Archambault, L., J. Morissette and M. Bernier-Cardou. 1998. Forest succession over a 20-year period following clearcutting in balsam fir-yellow birch ecosystems of eastern Québec, Canada. For. Ecol. Manage. 102: 61-74.

Batzer, H.O. and M.P. Popp. 1985. Forest succession following a spruce budworm outbreak in Minnesota. For. Chron. 61: 75-80.

Bédard, J., M. Crête and E. Audy. 1978. Short-term influence of moose upon woody plants of an early seral wintering site in Gaspé Peninsula, Quebec. Can. J. For. Res. 8: 407-415.

Bell, F.W., M.T. Ter-Mikaelian and R.G. Wagner. 2000. Relative competitiveness of nine early-successional boreal forest species associated with planted jack pine and black spruce seedlings. Can. J. For. Res. 30: 790-800.

Bergeron, Y. and M. Dubuc. 1989. Succession in the southern part of the Canadian boreal forest. Vegetatio 79: 51-63.

Boer, B. 2000. Sustainability law for the new millennium and the role of environmental legal education. Water Air Soil Poll. 123: 447-465. Cairns, M.A. and R.A. Meganck. 1994. Carbon sequestration, biological diversity, and sustainable development: integrated forest management. Environ. Manage. 18: 13-22.

Carleton, T.J. and P. MacLellan. 1994. Woody vegetation responses to fire versus clear-cutting logging: a comparative survey in the central Canadian boreal forest. Écoscience 1: 141-152.

Chapin, F.S., M.S. Torn and M. Tateno. 1996. Principles of ecosystem sustainability. Am. Nat. 148: 1016-1037.

De Grandpré, L., L. Archambault and J. Morissette. 2000. Early understory successional changes following clearcutting in the balsam fir-yellow birch forest. Écoscience 7: 92-100.

Di Castri, F. 1995. Les quatre piliers du développement durable. Nature \& ressources 31: 2-7.

Gouvernement du Québec. 1996. Règlement sur les normes d'intervention dans les forêts du domaine public. Décret 498-96, loi sur les forêts, gazette officielle du Québec: 2750-2786.

Hall, J.P. 2001. Criteria and indicators of sustainable forest management Environ. Monit. Assess. 67: 109-119.

Harvey, B.D., A. Leduc and Y. Bergeron. 1995. Early postharvest succession in relation to site type in the southern boreal forest of Quebec. Can. J. For. Res. 25: 1658-1672.

Hébert, R. 2000. Importance du processus naturel de régénération de la forêt mature mixte pour l'alimentation du lièvre d'Amérique, de l'orignal et de l'ours noir. M.Sc. thesis, Université Laval, Québec: 104 p. Hughes, J.W. and T.J. Fahey. 1991. Colonization dynamics of herbs and shrubs in a disturbed northern hardwood forest. J. Ecol. 79: 605-616. Jickling, B. 2000. A future for sustainability? Water Air Soil Poll. 123: 467-476.

Jobidon, R. 1997. Stump height effects on sprouting of mountain maple, paper birch and pin cherry - 10-year results. For. Chron. 73: 590-595.

Jobidon, R. 2000. Density-dependant effects of northern hardwood competition on selected environmental resources and young white spruce (Picea glauca) plantation growth, mineral nutrition, and stand structural development - a 5-year study. For. Ecol. Manage. 130: 77-97. Jobidon, R. and L. Charette. 1997. Effets, après 10 ans, du dégagement manuel simple ou répété et de la période de coupe de la végétation de compétition sur la croissance de l'épinette noire en plantation. Can. J. For. Res. 27: 1979-1991.

Kessell, S. 1981. The challenge of modeling post-disturbance plant succession. Environ. Manage. 5: 5-13.
Laflèche, V., J.-C. Ruel and L. Archambault. 2000. Évaluation de la coupe avec protection de la régénération et des sols comme méthode de régénération de peuplements mélangés du domaine bioclimatique de la sapinière à bouleau jaune de l'est du Québec, Canada. For. Chron. 76: 653-663.

Lalumière, R. and M. Thibault. 1988. Les forêts du parc national de la Mauricie, au Québec. Les presses de l'Université Laval, Québec: $495 \mathrm{p}$.

Lautenschlager, R.A. 1999. Environmental resource interactions affect red raspberry growth and its competition with white spruce. Can. J. For. Res. 29: 906-916.

Lei, T.T. and M.J. Lechowicz. 1990. Shade adaptation and shade tolerance in saplings of three Acer species from eastern North America. Oecologia 84: 224-228.

Lemons, J. 1995. Sustainable development and environmental protection: a perspective on current trends and future options for universities. Environ. Manage. 19: 157-165.

MacLean, D.A. and M.G. Morgan. 1983. Long-term growth and yield response of young Fir to manual and chemical release from shrub competition. For. Chron. 59: 177-183.

Marie-Victorin, F.E.C. 1995. Flore laurentienne, troisième édition Les presses de l'Université de Montréal, Montréal: 1083 p.

Miller, K.R. 1994. International cooperation in conserving biological diversity: a world strategy, international convention, and framework for action. Biodivers. Conserv. 3: 464-472.

Ministère des Ressources naturelles du Québec. 2000a. Our forest inheritance, introduction of the Bill to amend the Forest Act and Sittings of the General Parliamentary Standing Committee 2000. Gourvernement du Québec, Ministère des Ressources naturelles: $32 \mathrm{p}$.

Ministère des Ressources naturelles du Québec. 2000b. La forêt mixte, un heureux mélange. Gouvernement du Québec, Ministère des Ressources naturelles: non paginé.

Norton, T.W. 1996. Conservation of biological diversity in temperate and boreal forest ecosystems. For. Ecol. Manage. 85: 1-7.

Oliver, C.D. 1981. Forest development in North America following major disturbances. For. Ecol. Manage. 3: 153-168.

Post, L.J. 1970. Dry-matter production of mountain maple and balsam fir in northwestern New Brunswick. Ecology 51: 548-550. Prance, G.T. 1995. Systematics, conservation and sustainable development. Biodivers. Conserv. 4: 490-500.

Ricard, J.-P. and C. Messier. 1996. Abundance, growth and allometry of red raspberry (Rubus idaeus L.) along a natural light gradient in a northern hardwood forest. For. Ecol. Manage. 81: 153-160. Ruel, J.-C. 1992. Impact de la compétition exercée par le framboisier (Rubus idaeus L.) et les feuillus de lumière sur la croissance du sapin (Abies balsamea (L.) Mill.) en génération. Can. J. For. Res. 22 1408-1416.

Upreti, G. 1994. Environmental conservation and sustainable development require a new development approach. Environ. Conserv. 21: $18-29$.

Vallée, J., R. Couture and R. Joyal. 1976. Étude de la régénération après coupe des essences composant la diète alimentaire de l'orignal. Phytoprotection 57: 155-164.

Vincent, A.B. 1965. Growth habits of mountain maple in the Ontario clay belt. For. Chron. 41: 330-344.

Whitney, G.G. 1982. The productivity and carbohydrate economy of a developing stand of Rubus idaeus. Can. J. Bot. 60: 2697-2703. Whitney, G.G. 1986. A demographic analysis of Rubus idaeus and Rubus pubescens. Can. J. Bot. 64: 2916-2921. 